\title{
The effect of experimental streptococcus infection in myocarditis on some biochemical and inflammatory markers in albino rats
}

\author{
*Kholoud $\mathrm{SR}^{1,2}$, Iman $\mathrm{MKA}^{3}$, Rasha $\mathrm{EH}^{2}$, Soha SSA ${ }^{2}$
}

1. Department of Biochemistry, Faculty of Girls Science, King Abdulaziz University, Jeddah, Saudi Arabia.

2. Biochemistry Department, Faculty of Science, Ain Shams University, Cairo, Egypt.

3. Department of hydrobiology, National Research Center, Cairo, Egypt.

\begin{abstract}
Background:Myocarditis is an uncommon disease that presents with a wide range of symptoms in children and adults. It is histologically characterized by varying degrees of myocardialnecrosis, edema and cellular infiltration myocardial inflammation is a nonspecificresponse to many triggers such as bacterial infection, cardio toxic agents, ormechanical injury.

Objective: This study was carried out to investigate the experimental Streptococcus

faecalis induction of myocarditis and its effect on some blood parameters, inflammatory markers and histopathological changes in male albino rats.

Methods: Rats were infected by intraperitoneal injection of $108 \mathrm{CFU} / \mathrm{ml}$ of Streptococcus faecalis and sacrificed after one, two and seven days post infection. Biochemical analyses of blood were carried out to investigate the serum biomarkers of inflammation, liver function tests, cardiac enzymes \& kidney function tests.

Results: All biochemical analyses showed statistically significant increase in the measured parameters due to bacterial infections except for blood urea which appear to be normal. A significant positive correlation was observed between lactate dehydrogenase enzyme $(\mathrm{LDH})$ with creatinine $(\mathrm{r}=0.778, \mathrm{P}<0.01)$. In the 7 days group, there were significant positive correlations between aspartate aminotransferase (AST) and alanine aminotransferase (ALT) $(r=0.675, \mathrm{P}<0.05)$, erythrocyte sedimentation rate $(\mathrm{ESR})$ with Urea $(\mathrm{r}=0.659, \mathrm{P}<0.05)$ and alkaline phosphatase $(\mathrm{ALP})$ with $\mathrm{C}$-reactive protein $(\mathrm{CRP})$ $(\mathrm{r}=0.765, \mathrm{p}<0.01)$.

Conclusion: Many of these biomarkers will provide important new insights into pathophysiology and aid in the diagnosis and management of cardiovascular patients.

Key words: Cardiovascular diseases, Myocarditis, Rat, Streptococcus faecalis, C-reactive protein.

African Health Sciences 2013; 13(4): 1062 - 1070 http://dx.doi.org/10.4314/ahs.v13i4.29
\end{abstract}

\section{Introduction}

Myocarditis is an uncommon disease that presents with a wide range of symptoms in children and adults. It is histologically characterized by varying degrees of myocardialnecrosis, edema and cellular infiltration myocardial inflammation is a nonspecificresponse to many triggers such as bacterial infection, cardio toxic agents, ormechanical injury. Bacteremia from any source may result in myocarditis, with the most common pathogens being, streptococcus, and Listeria ${ }^{1}$. Nonspecific serum markers of inflammation, including erythrocyte sedimentation rate, C-reactive protein,

\begin{tabular}{|l|}
\hline *Corresponding author: \\
Kholoud S. Ramadan \\
Department of Biochemistry \\
Faculty of Girls Science, King Abdulaziz \\
University \\
Jeddah, Saudi Arabia \\
Tel: 0551291289 \\
E-mail: ramadankholoud@yahoo.com
\end{tabular}

and leukocyte count, are usually elevated but are not used for diagnosis of acute myocarditis. Cardiac biomarkers of myocardial injury are not elevated in most patients with myocarditis but, if elevated, may be helpful to confirm the diagnosis ${ }^{2}$.

Inflammatory response can be measured by a variety of inflammatory biomarkers. The largest database so far has been accumulated for C-reactive protein ${ }^{3}$. C-reactive protein (CRP) is an acute phase reactant with roles in innate host defense, clearance of damaged cells, and regulation of the inflammatory response.

The aim of the present study is to examine the Streptococcus induction of cardiovascular diseases exemplified by myocarditis in rats. The effect of Streptococcus infection upon some serum inflammation markers, liver, cardiac enzymes and other parameters from a biochemical point of view was examined. 


\section{Methods}

\section{Animals}

Ten weeks old male Swiss albino rats $(\mathrm{n}=40)$ weighing 150-200 g were maintained on a diet of ad libitum and tap water. These experiments have been approved by Ain Shams University committee on the use and care of Laboratory animals. After 2 -weeks as a conditioning period, the animals were randomly distributed into 2 groups.

One group ( $\mathrm{n}=10)$ was treated as a control group, left without injection. The other group $(n=30)$ was treated as the experimental group, anesthetized with ketamine, and were intraperitoneal injected with a fresh culture of Streptococcus faecalis. Rats were sacrificed after 1, 2 and 7 days from infection with bacteria.

\section{Bacterial source}

The organism used was (Enterococcus faecalis: reference strain with ATCC: 29212).

This strain was supplied from the faculty of veterinary medicine, Cairo University at

Giza. The organism was grown for 18 hours at $37^{\circ} \mathrm{C}$ in glucose broth medium (Enriched media) and aliquots of the initial culture were inoculated into fresh media with $15 \%$ glycerol for storing and frozen at $-20{ }^{\circ} \mathrm{C}$ until used. Frozen aliquots were thawed, kept at 37 ${ }^{\circ} \mathrm{C}$ for 6 hours, and subcultured in fresh media for 18 hours prior to injection. The bacteria were cultured to approximately $\mathrm{CFU} / \mathrm{ml}$. Estimations of cell density were determined by measuring the absorbance at 620 $\mathrm{nm}$ and verified by plate counts. Quantitation of cultures was done by serial dilutions \& plates were counted after overnight incubation with a bright light source. A fresh culture of bacteria was prepared (24 hours culture) and $1 \mathrm{ml}$ of this culture was injected in the experimental group.

\section{Infection with Bacteria and sample collection}

Rats were infected by intraperitoneally injection of $10^{8} \mathrm{CFU} / \mathrm{ml}$ of bacterial strain suspended in $1 \mathrm{ml}$ of glucose broth medium. Blood was collected from the retro orbitalsinus for analysis of early blood clearance of bacteria. The samples were clotted,

Centrifuged at $4000 \mathrm{~g}$ for 10 minutes, and stored at $70^{\circ} \mathrm{C}$. Samples were stored at this temperature until assayed.

The separated serum was assayed for C-reactive protein by latex agglutination method ${ }^{4}$, using accurate creative protein reagent latex test diagnostic kit (Labcare Diagnostics India Pvt Ltd). Leucocytes count and erythrocyte sedimentation rate (ESR) were carried out using the method adapted by Simmons and Bernard . Aspartate aminotransferase (AST), alanine aminotransferases (ALT) and alkaline phosphate (ALP)

African Health Sciences Vol 13 Issue 4 December 2013 activities were measured using QCA kits (Quimica Clinica Aplicada S.A. kits. Aspartado, Amposta, Spain) (Reitman and Frankel; Belfield and Goldberg6, ${ }^{6}$. Creatine phosphokinase (CPK), lactate dehydrogenase $(\mathrm{LDH})$ activity and urea, creatinine and uric acid level were assayed using Span diagnostic kits.

\section{Histopathological diagnosis of myocardial infarction}

Autopsy samples were taken from the liver and heart of rats in different groups and fixed in $10 \%$ formal saline for 24 hours. Washing was done in tap water then serial dilutions of alcohol (methyl, ethyl and absolute ethyl) were used for dehydration.

Specimens were cleared in xylene and embedded in paraffin at $56{ }^{\circ} \mathrm{C}$ in hot air oven for 24 hours. Paraffin bees wax tissue blocks were prepared for sectioning at 4 microns by slide microtome. The obtained tissue sections were collected on glass slides, deparaffinized and stained by hematoxylin and eosin stains ${ }^{8}$ for histopathological examination through the light microscope.

\section{Statistical analysis}

Data were presented as mean \pm S.D. (standard deviation). Differences among all groups were assessed using a one-way analysis of variance (ANOVA) to determine significant differences between the mean values at the $95 \%$ confidence level followed by the Duncan multiple comparison test as a post hoc test. Pearson's correlation coefficients were used to describe the association between different serum parameters that were measured in this study. The analyses were made using the Statistical Package for Social Sciences Software (SPSS, version 16). A $p$-value less than 0.05 were considered statistically significant.

\section{Results}

This study was performed on four groups of rats; each group is composed of ten rats

$(n=10)$. Three of the four groups were injected by Streptococcus faecalis and the fourth group was treated as control group and was injected by saline. All rats in the experimental three groups developed myocarditis. This was proved, after sacrificing the animals on different intervals of time (after 1 day, 2 days and 7 days), through a series of biochemical, molecular and histological investigations. However, the animals infected with bacteria showed no signs of illness that can be investigated exteriorly.

\section{Biochemical analyses of Blood Biomarkers of inflammation}

Biochemical changes which are associated with inflammation are summarized in figure 1. CRP 
concentrations were markedly elevated with maximal values $94.8 \pm 3.79$ at 1 day after injection. This corresponds to about 16 fold increase compared with control levels (figure 1). The ESR levels usually increased at $24 \mathrm{hr}$ post injection $(\mathrm{P}<0.0001)$.

After 2 days and 7 days, the ESR concentration was decreased but the values are still higher than control. Absolute WBC counts were significantly elevated at 1 week after injection.

\section{Biochemical markers of liver}

Changes in liver enzymes levels due to bacterial infections are reported in table 1.The serum AST and ALP activities of rats treated with bacteria were significantly higher $(\mathrm{P}<0.0001)$ than the control. A rise in AST is due to cellular injury in liver that may increase AST level in serum. The ALP activities of infected rats were also significantly higher $(\mathrm{P}<0.0001)$ than those in control rats. A rise in ALP activities has been linked with an increased osteoblastic activity and lack of bile flow. Moreover, there was a trend towards a statistically significant elevation of serum ALT activity by 1 day. Between 2 days and 7 days, the activity returned to decrease. ALT is principally found in the liver and is regarded as being more specific than AST for detecting liver cell damage. The lower ALT values in rats indicate liver function improvement brought by bacteria. Hepatocytes play a major role in absorbing and metabolizing many toxic chemicals. They are therefore liable to injury by various chemicals, including food.

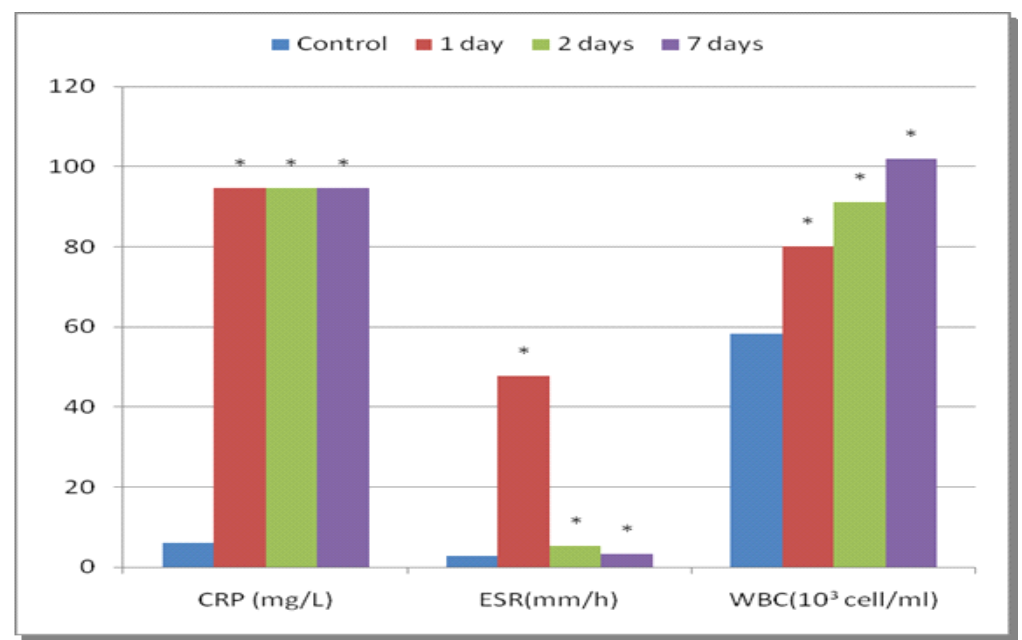

Figure 1: Changes in blood inflammation biomarkers of different studied groups at different intervals of time after bacterial injection

Table 1: Serum liver profile of control healthy rats and infected rats (Data are presented as mean \pm S.D)

\begin{tabular}{|c|c|c|c|}
\hline Parameters/ Groups & $\operatorname{AST}(\mathrm{U} / \mathrm{L})$ & ALT(U/L) & $\operatorname{ALP}(\mathrm{U} / \mathrm{L})$ \\
\hline \multicolumn{4}{|l|}{ N.C } \\
\hline Mean \pm S.D & $44.5 \pm 3.4^{\mathrm{a}}$ & $22.6 \pm 2.59^{a}$ & $131 \pm 12.9^{a}$ \\
\hline Range & $(42-46)$ & $(20-24)$ & $(122-140)$ \\
\hline \multicolumn{4}{|l|}{ 1 Day } \\
\hline Mean \pm S.D & $117.5 \pm 4.03^{\mathrm{b}}$ & $34.8 \pm 3.2^{\mathrm{b}}$ & $220 \pm 11.8^{\mathrm{b}}$ \\
\hline Range & $(114-120)$ & $(32-37)$ & $(212-229)$ \\
\hline Change $\%$ & $164 \%$ & $53.9 \%$ & $67 \%$ \\
\hline \multicolumn{4}{|l|}{2 Days } \\
\hline Mean \pm S.D & $158.9 \pm 3.8^{c}$ & $17.6 \pm 1.8^{\mathrm{c}}$ & $130.7 \pm 13^{a}$ \\
\hline Range & $(156-161)$ & $(16-18)$ & $(120-140)$ \\
\hline Change $\%$ & $257 \%$ & $22.12 \%$ & $-0.68 \%$ \\
\hline \multicolumn{4}{|l|}{7 Days } \\
\hline Mean \pm S.D & $317.6 \pm 20.6^{\mathrm{d}}$ & $11.4 \pm 3.5^{\mathrm{d}}$ & $125.6 \pm 6.7^{\mathrm{a}}$ \\
\hline Range & $(302-332)$ & $(8.8-13.9)$ & $(120-130)$ \\
\hline Change $\%$ & $613.7 \%$ & $49.5 \%$ & $-4.55 \%$ \\
\hline F-ratio & $113.7 * * *$ & $119.38^{* * *}$ & $155.8^{* * *}$ \\
\hline LSD & 41 & 5 & 0.9 \\
\hline
\end{tabular}

Similar characters denote insignificance between groups. ${ }^{* * *}$ denote statistical significance at $\mathrm{p}<0.001$. The mean difference is significant at $\mathrm{p}<0.05$. 


\section{Cardiac Biomarker Enzymes}

Animals treated with bacteria produced a significant $(\mathrm{P}<0.01)$ increase in the level of CPK and LDH as compared with the rats in control group, table 2 . Elevated levels of LDH usually indicate some type of tissue damage. Also, elevated levels of CPK represent a mark for myocardial damage. $\mathrm{LDH}$ and CPK levels typically were raised as the cellular destruction begins, peak after some time period, and then begin to fall.

\section{Biochemical markers of kidney}

There was no significant difference in serum urea concentration measured at time $24 \mathrm{~h}$ between experimental (bacterial treated) and control group of rats $(13.87 \pm 0.88 \mathrm{mg} / \mathrm{dl}$ vs. $15.35 \pm 1.8 \mathrm{mg} / \mathrm{dl}$, $\mathrm{P}>0.05)$. The serum urea concentration remained almost unchanged at 2 days and 7 days post infection $(16.82 \pm 1.3$ and $15.22 \pm 0.88 \mathrm{mg} / \mathrm{dl}$, at 2 days and 7 days post infection, respectively), table 3 . In contrast, there was a trend toward an elevation of serum creatinine and uric acid (UA) levels after 1 day that became pronounced and statistically significant after 2 days. After 7 days, the levels returned to normal. This indicates that the animal's kidney was not affected.

Table 2: Serum Heart profile of control healthy rats and infected rats (Data are presented as mean \pm S.D)

\begin{tabular}{lll}
\hline Parameters $/$ Groups & CPK (U/L) & LDH (U/L) \\
\hline N.C & & \\
Mean \pm S.D & $200 \pm 8.8^{\mathrm{a}}$ & $398.9 \pm 27^{\mathrm{a}}$ \\
Range & $(193.6-206.3)$ & $(378.9-418.8)$ \\
$\mathbf{1}$ Day & & \\
Mean \pm S.D & $520 \pm 16.4^{\mathrm{b}}$ & $603.7 \pm 15.1^{\mathrm{b}}$ \\
Range & $(508.7-532.2)$ & $(592.8-614.5)$ \\
Change $\%$ & $160 \%$ & $51.3 \%$ \\
$\mathbf{2}$ Days & & \\
Mean \pm S.D & $605 \pm 26.7^{\mathrm{c}}$ & $718.5 \pm 12.5^{\mathrm{c}}$ \\
Range & $(586.5-624.8)$ & $(709.5-4.72)$ \\
Change $\%$ & $202^{\circ} \%$ & $80 \%$ \\
7 Days & & \\
Mean \pm S.D & $783.3 \pm 21.5^{\mathrm{d}}$ & $849.4 \pm 42.7^{\mathrm{d}}$ \\
Range & $(767.8-798.7)$ & $(818.8-879.9)$ \\
Change $\%$ & $291 \%$ & $112.9^{\%}$ \\
F-ratio & $156.3^{* * *}$ & $487.5^{* * *}$ \\
LSD & 85.2 & 114.8 \\
\hline
\end{tabular}

Similar characters denote insignificance between groups. ${ }^{* * *}$ denote statistical significance at $\mathrm{p}<0.001$. The mean difference is significant at $\mathrm{p}<0.05$.

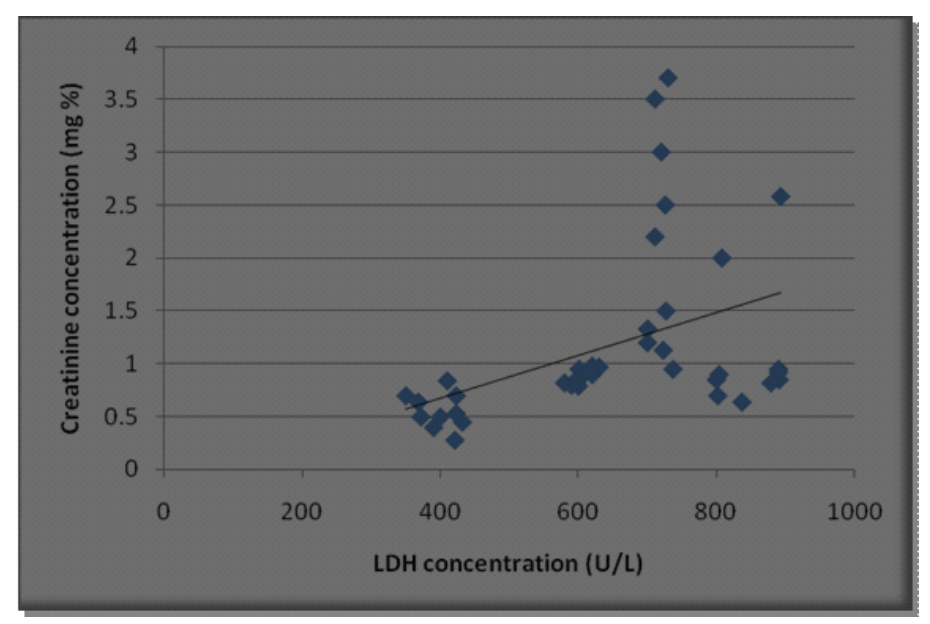

Figure 2: Correlation study between LDH and Creatinine in 1 day group 
Table 3: Serum kidney profile of control rats and infected rats (Data are presented as mean \pm S.D)

\begin{tabular}{lll}
\hline $\begin{array}{l}\text { Parameters } \\
\text { Groups }\end{array}$ & \multicolumn{1}{c}{ CPK(U/L) } & \multicolumn{1}{c}{ LDH (U/L) } \\
\hline $\begin{array}{l}\text { N.C } \\
\text { Mean } \pm \text { S.D }\end{array}$ & $200 \pm 8.8^{\mathrm{a}}$ & $398.9 \pm 27^{\mathrm{a}}$ \\
$\begin{array}{l}\text { Range } \\
\text { 1 Day }\end{array}$ & $(193.6-206.3)$ & $(378.9-418.8)$ \\
Mean \pm S.D & $520 \pm 16.4^{\mathrm{b}}$ & $603.7 \pm 15.1^{\mathrm{b}}$ \\
Range & $(508.7-532.2)$ & $(592.8-614.5)$ \\
Change $\%$ & $160 \%$ & $51.3 \%$ \\
2 Days & & \\
Mean \pm S.D & $605 \pm 26.7^{\mathrm{c}}$ & $718.5 \pm 12.5^{\mathrm{c}}$ \\
Range & $(586.5-624.8)$ & $(709.5-4.72)$ \\
Change \% & $202 \%$ & $80 \%$ \\
7 Days & & \\
Mean \pm S.D & $783.3 \pm 21.5^{\mathrm{d}}$ & $849.4 \pm 42.7^{\mathrm{d}}$ \\
Range & $(767.8-798.7)$ & $(818.8-879.9)$ \\
Change \% & $291 \%$ & $112.9^{*} \%$ \\
F-ratio & $156.3^{* * *}$ & $487.5^{* * *}$ \\
LSD & 85.2 & 114.8 \\
\hline
\end{tabular}

Similar characters denote insignificance between groups. $* *$ denote statistical significance at $\mathrm{p}<0.01$. *** denote statistical significance at $\mathrm{p}<0.001$. The mean difference is significant at $\mathrm{p}<0.05$.

The current study revealed that in the first group (1 day), there was a significant positive correlation between $\mathrm{LDH}$ and creatinine $(\mathrm{r}=0.778$, at $\mathrm{P}<0.01)$. This correlation was represented in figure (2), ESR with Urea $(\mathrm{r}=0.659$, at $\mathrm{P}<0.05)$, shown in figure 3.

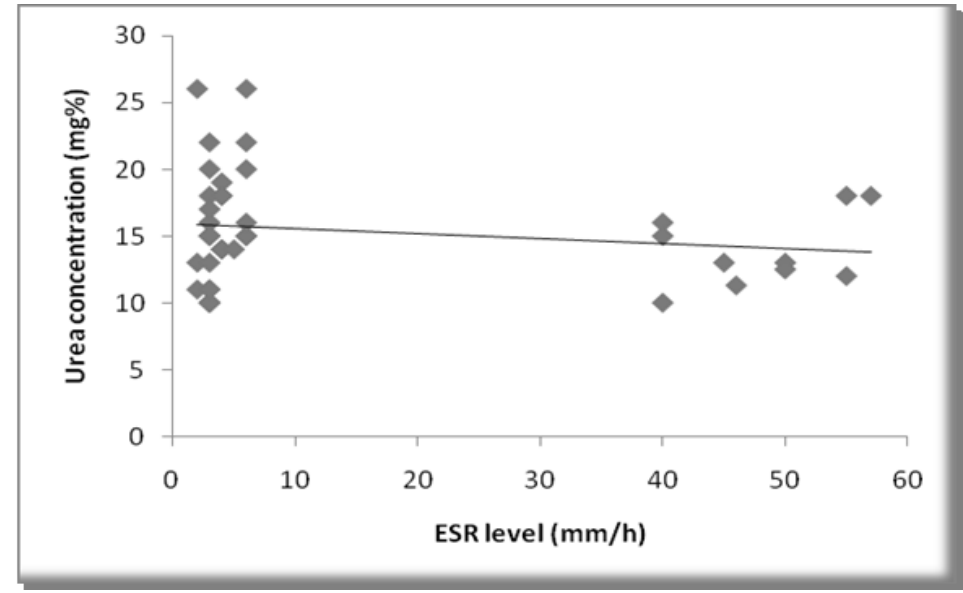

Figure 3: Correlation study between urea and ESR in 2 days group
In the 7 days group, there were significant positive correlations between AST and ALT ( $r=0.675$, $\mathrm{P}<0.05)$, shown in figure 4 and ALP with $\mathrm{CRP}(\mathrm{r}=0.765$, at $\mathrm{p}<0.01)$, as shown in figure 5 . 


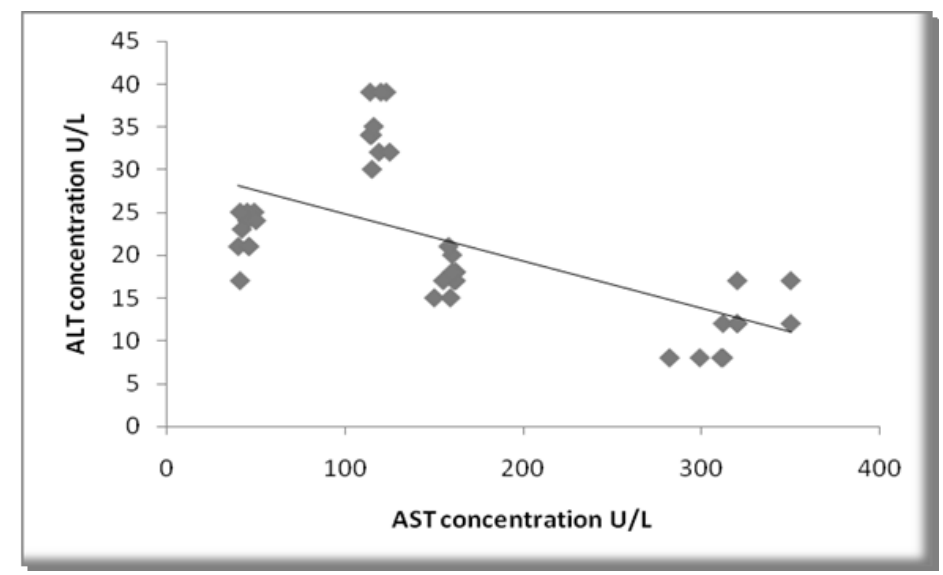

Figure 4: Correlation study between ALT and AST in 7 days group

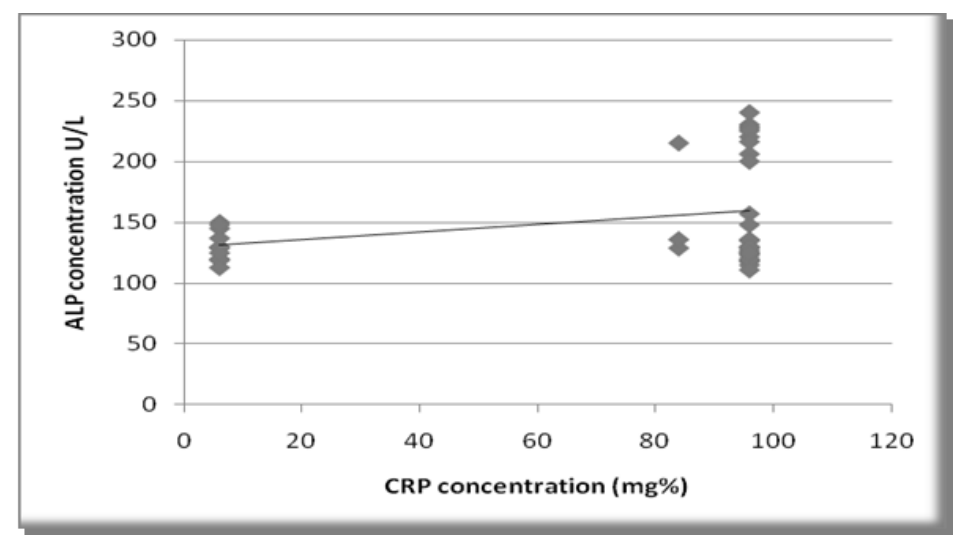

Figure 5: Correlation study between ALP and CRP in 7 days group

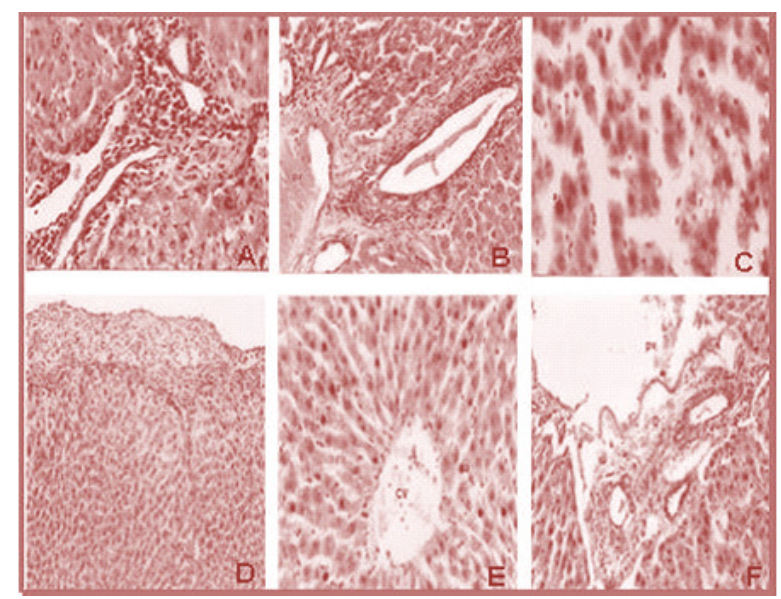

Figure 6: Histological appearance of liver sections stained with Haematoxylin and Eosin of: (A) Massive number of inflammatory cell infiltration in the portal area after one day from infection. (B)dilation and congestion in the portal vein (pv) and dilationof bile duct (bd) with periductal inflammatory cells infiltration after one day from infection. (C)Apoptosis (a) and mild fatty change ( $f$ ) in hepatocytes after bacterialinfection by two days. (D) thickening of the hepatic capsule (c) and infiltrated byinflammatory cells and fibrin threads after seven days from infection.(E)Apoptosis inmost of hepatocytes (a).(F) Dilation in the portal vein (pv) with inflammatory cells infiltration $(\mathrm{m})$ in the portal area surrounding the bile duct (o) after seven days frominfection. 


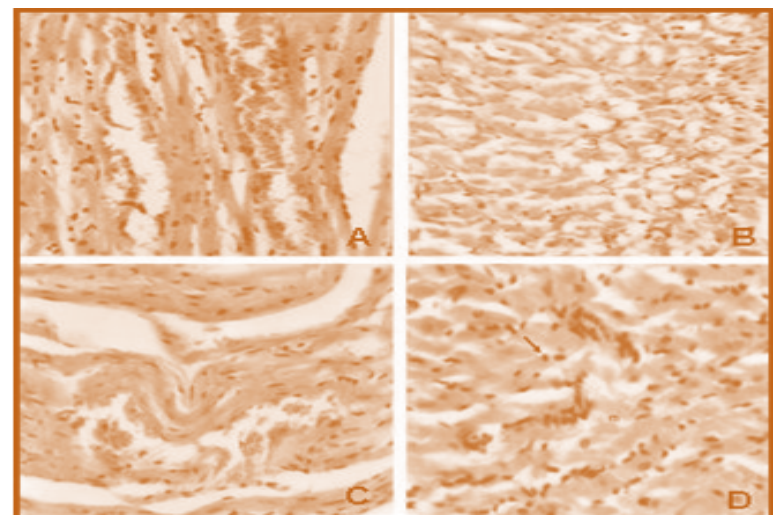

Figure 7: Histological appearance of heart sections stained with Haematoxylin and Eosin of: (A) Infected heart rat after one day showing focal hemorrhages in between the myocardial bundles (h). (B) infected rat after two days showing degeneration of myocardial muscle cells (m). (C) focal hemorrhages (h) in between the myocardial bundles after bacterial infection by two days. (D) infected rat showing inflammatory cells infiltration (arrow) in between myocardial bundles (m) after bacterial infection by seven days.

\section{Discussion}

Bacteremia from any source may result in myocarditis, with the most common pathogens being, streptococcus, and Listeria ${ }^{1}$. The present study was concerned with bacterial myocarditis associated with biochemical changes induced in rats experimentally infected with Streptococcus faecalis. The experiment was carried out on four groups of rats, each group is composed of ten rats $(n=10)$. Three of the four groups were injected by $S$. Faecal is intraperitoneally and the fourth group was treated as control group and was injected by saline. All rats in the experimental three groups developed myocarditis. This was proved, after sacrificing the animals on different intervals of time (after 1 day, 2 days and 7 days), through a series of biochemical and histological investigations. These investigations were carried out on different intervals of time (one, two and seven days) after bacterial infection.

Previous studies have provided evidence that there is no replicable and consistent gold standard for diagnosis, which is typically made using a combination of clinical findings in association with the results of biochemical testing, non-invasive imaging and biopsy-derived analyses. Currently, no single clinical or imaging finding confirms the diagnosis of myocarditis with absolute certainty. Depending on the severity and time of testing during the course of disease, serum biomarkers of myocardial injury such as creatine kinase, creatine kinase-myocardial band and troponin may beincreased?.
By comparing the serum biochemical markers that were investigated for the infected groups in this study with those for the control group, we found that injection of rats with sterile physiological saline induced no change in serum biomarkers, indicating that alterations following the bacterial injection were due to specific action of the bacteria.

The studied serum biomarkers for inflammation were found statistically significant to be increased in the three experimental groups of rats compared to control group. Absolute WBC counts were significantly elevated at 1 week after injection. The ESR levels increased at $24 \mathrm{hr}$ post injection $(\mathrm{P}<0.0001)$. After 2 days and 7 days, the ESR concentration was decreased but the values are still higher than control. This elevation in total leukocytes is in harmony with the results of Shimada et al. ${ }^{10}$ in their model of myocarditis. Also, these results were matched with those of Kang et al ${ }^{11}$ which showed that the initial laboratory tests in patients with myocarditiscan show leukocytosis, eosinophilia, elevated erythrocyte sedimentation rate, and increased levels of cardiac troponins or of the creatinine kinase MB isoenzyme.

CRP measurement is recommended as the first-line method of screening of suspected bacterial inflammation ${ }^{12}$. In the present study serum CRP level was found statistically significant to be markedly elevated with maximal values $94.8 \pm 3.79$ at 1 day after injection of bacteria in the three experimental groups. This elevation continues after seven days from infection. These results match those of Latini 
et $\mathrm{al}^{13}$ in which plasma CRP peaked later, between 24 and $48 \mathrm{~h}$ after the first symptoms in patients with myocardial infarction.

In the present study, serum level of creatine kinase $(\mathrm{CK})$ and lactate dehydrogenase $(\mathrm{LDH})$ was found statistically significant to be increased in the three experimental groups of rats compared to the control group. This elevation resembles that was found by Gupta et $\mathrm{al}^{14}$. Since the release rate is flow dependent, especially for CK-MB, early marker elevations may be of less significance than later, perhaps even lower, marker elevations. Myocardial release rates of biomarkers may also vary under different clinical conditions ${ }^{15}$.

Serum chemistry testing to look at end organ function is also imperative formyocarditis. In this study, serum liver enzymes were investigated and the results showed that the liver was aggressively affected with the bacterial infection. This was shown by the significantly elevation of AST, ALT and ALP enzymes in the infected groups of rats ${ }^{11}$.

It is clear from the work of a number of previous investigators that the measurement of enzymatic activity is an extremely sensitive index by which to detect alterations brought about by infections. Increases in serum levels of enzymes which are ubiquitous in their distribution, however, are less specific. Nevertheless, in this study elevated levels of enzymes of intermediary metabolism such as LDH and ALP indicate systemic response due to bacterial infection ${ }^{16}$.

In the present study, there was a trend towards a statistically significant elevation of serum ALT and ALP activity by 1 day. Between 3 days and 7 days, the activity returned to decrease. These results are in harmony with those of Theleman et $\mathrm{al}^{16}$. A rise in ALP activities has been linked with an increased osteoblastic activity and lack of bile flow. This had been demonstrated in pigs and in rats ${ }^{17}$.

The changes in amino transferases activities were consistent with histological evaluation that revealed enhanced hepatocellular oncosis in treated animals. Based on the nature of the histopathologic lesions, it showed aggressive changes in the tissues as shown in results previously, which indicates that liver injury occurred by the bacteria. The present study revealed that infection with bacteria altered serum enzyme levels toa greater degree. Thus, any external stressor, even at a sublethal dose can have atoxicological effect on the liver and other tissues and increased the level of $\mathrm{LDH}$ and CPK which all correlate to liver function and muscle lesions, including myocardial.
Similarly, high levels of LDH in CSF have been associated with bacterial meningitis. In agreement with these findings, elevated levels of LDH were detectable in serum, brain and intestine of rat pups infected with Omp Ab ES compared with the control group. Multiplication of bacteria within the central nervous system compartment triggers a host response with an overshooting inflammatory reaction, which leads to brain parenchymal damage. The inflammatory response is due, in large part, to the activity of cytokines, which play an important role in deciding the ultimate outcome of an infection during meningitis ${ }^{18}$.

Renal dysfunction has been associated with adverse cardiovascular outcomes ${ }^{19}$. In the present study, kidney functions were investigated through estimation of serum blood urea nitrogen, serum creatinine and serum uric acid level. Serum urea was none significantly different in the three experimental groups when compared to the control group, but serum creatinine and uric acid levels were found statistically significant to be increased in the experimental groups after bacterial infection by two days then decreased after seven days from the bacterial infection. Serum blood urea nitrogen(BUN) levels, however, may provide supplemental information in regard to renal function as renal proximal tubule cells may increase BUN reabsorption in the setting of increased neurohormonal activation ${ }^{20}$, Therefore, our results indicate that renal function are not affected here by the bacterial infection. These findings are contradicted with those of Kang et al. ${ }^{11}$ which showed increase in serum blood urea nitrogen level. The findings for serum creatinine level are in agreement with those bf Kang et al. ${ }^{11}$ while; they are contradicted with the findings of Thelemanet al ${ }^{16}$. The increase in serum uric acid can indicate inflammation in joint which associated with cardiovascular disease ${ }^{21}$. Phu et al. ${ }^{22}$ stated that Staphylococci and Streptococci cause immune complex glomerulo-nephritis in $20 \%$ or more of cases, presenting as proteinuria, haematuria and renal impairment. This is contradicted with our results which showed that norenal impairment results from the bacterial infection.

\section{Conclusion}

Many of these biomarkers will provide important new insights into pathophysiology and aid in the diagnosis and management of cardiovascular patients. However, as with all rapidly expanding fields, 
there is the risk of excessive enthusiasm unless we are circumspect about the data that guide the clinical use of these new tools. Many of the new biomarkers will overlap substantially, and their use likely will not be synergistic but duplicative. It will take some time to sort out which biomarkers are of clinical diagnostic and/or prognostic value.

\section{References}

1. Blauwet LA, Cooper LT. Myocarditis. Prog. Cardiovasc. Dis., 2010;52:274-288.

2. Smith SC, Ladenson JH, Mason JW, et al. Elevations of cardiac troponin associated with myocarditis (Experimental and clinical correlates).Circulation 1997; 95:163-168.

3. Kolz W, Koenig W, Muller M, Andreani M, Greven $\mathrm{S}$, et al. DNA variants, plasma levels and variability of $\mathrm{C}$-reactive protein in myocardial infarction survivors: results from the AIRGENE study. European Heart Journal 2008; 29:1250-1258.

4. Singer JM, Piot CM, Parker E, Elster SF. The latexfixation test. III. Agglutination test for C-reactive proteins and comparison with the capillary precipitin method. Am J Clin Path. 1975; 28: 611- 617.

5. Simmons $A$ and Bernard ES. Hematology (Combined Theoretical and Technical Approach). Butterworth -Heinemann. 1997; 255-81.

6. Reitman S, Frankel S, 0 . Colorimetric determination of serum GOT (glutamic oxaloacetic transaminase) GPT (glutamic pyruvic transaminase) activity. $\mathrm{Am}$. J. Clin. Pathol. 1957, 28:56.

7. Belfield A, Goldberg DM. Colorimetric determination of alkaline phosphatase activity. Ensyme 1971; 12:561-568.

8. Banchroft JD, Stevens A and Turner DR. Theory and practice Of Histological Techniques. 1996; Fourth Ed. Churchil Livingstone, New York, London, San Francisco, Tokyo.

9. Friedrich MG, Sechtem U, Schulz-Menger J, Holmvang G, et al. Cardiovascular Magnetic Resonance in Myocarditis. A. JACC. 2009; 53(17):1475-1487.

10. Shimada K, Okabe TA, Mikami Y, Hattori M, Fujita $M$ and Kishimoto C. Therapy with granulocyte colony-stimulating factor in the chronic stage, but not in the acute stage, improves experimental autoimmune myocarditis in rats via nitric oxide. J. Molec. Cellu. Cardiolo. 2010; 49: 469481.

11. Kang TJ, Wu CC, Lu CW, Jean WH, Yang MH and Lin TY. Acute Myocarditis-related complete Atrioventricular block-An accidental finding in an acute appendicitis patient. Acta Anaesthesiol. 2008; 46(3): 138-141.

12. Korppi M, Heiskanen-Kosma T and Leinonen M. White blood cells, Creactive protein and erythrocyte sedimentation rate in pneumococcal pneumonia in children. Euro. Resip. J. 1997; 10: 1125-1129.

13. Latini R, Maggioni AP, Peri G, Gonzini L, Lucci D and Mocarelli P. Prognostic significance of the long pentraxin PTX3 in acute myocardial linfarction. Circulation 2004; 110: 2349-54.

14. Gupta S, Markham DW, Drazner MH and Mammen PP. Fulminantmyocarditis. Nature Clin. Prac. Cardio. Med. 2008; 5(11): 693-706.

15. Vatner SF, Baig H and Manders WT. Effects of coronary artery reperfusionon myocardial infarct size calculated from creatine kinase. J. Clin.Invest. 1978; 61: 1048-1056.

16. Theleman KP, Kuiper JJ and Roberts WC. Acute myocarditis (Predominately Lymphocytic) causing sudden death without heart failure. Amer. J. Cardiol. 2001; 88: 1078-1083.

17. Bertazzoni ME, Benini A, Marzotto M, Hendriks $\mathrm{H}$, Sbarbati A, and DellaglioF. Preliminary screening of health-promoting properties of new lactobacillusstrain: in vitro and in vivo. 2001; HEALFO abstracts, Italy.

18. Mittal R, Wang Y, Hunter CJ, Gomez IG and Prasadarao NV. Brain damage in newborn rat model of meningitis by Enterobacter sakazakii: a role for outer membrane protein A Laboratory Investigation, 2009; 89: 263-277.

19. Aronson D, Mittleman MA and Burger AJ. Elevated blood urea nitrogen level as a predictor of mortality in patients admitted for decompensated heart failure. Am. J. Med. 2004; 116:466-473.

20. Shlipak MG, Heidenreich PA, Noguchi H, Chertow GM, Browner WS and McClellan MB. Association in renal insufficiency with treatment and outcomes after myocardial infarction in elderly patients. Ann. Intern. Med. 2002; 137: 555-62.

21. Heinig $M$ and Johnson RJ. Role of uric acid in hypertension, renal disease, and metabolic syndrome. Clevel. Clinic. J. Med. 2006; 73(12): 10591064.

22. Phu NH, Hien TT, Mai TH, Hong Chau TT, Chuong LV, Loc PP, Winearls $\mathrm{C}$ et al. Hemofiltration and peritoneal dialysis in infectionassociated acute renal failure in Veitnam. The new Eng. J. Med. 2002; 347: 895-902. 